\title{
Copper in Horticulture
}

\author{
Denis Rusjan \\ Biotechnical Faculty, University of Ljubljana \\ Slovenia
}

\section{Introduction}

$\mathrm{Cu}$ as a solid, conductive chemical $(\mathrm{Cu})$ material has the ability to deform under tensile stress (ductile metal); its freshly exposed surface has a reddish-orange colour, it is easily recyclable and with an annual production of more than 5 million tons of copper nowadays, due to the increasingly vital part of the metal's use in many branches of modern technology, especially in architectural structures and electronic devices (Table 1), the material is gaining importance. Copper is an essential material of the future regarding solar heating, desalination of water, environmentally-sound cultivation practices in agriculture and its contribution to the production of linear motors. Its unique chemical characteristics provide for more than 200 year's use of $\mathrm{Cu}$ in phytochemistry especially in the role of fungicides.

$\mathrm{Cu}^{2+}$ and $\mathrm{Cu}^{+}$ions are soluble in water and provide antifungal and antibacterial effects (biostatic elements) at low concentration levels, wherefore their contribution to the production of fungicides is, up to the present day, irreplaceable. On the other hand high concentrations of copper salts affect physiological and biochemical processes in higher organisms. Copper takes part in numerous physiological processes and is an essential cofactor for many metalloproteins. However, copper excess leads to problems in cell function and metabolism, as copper surplus inhibits plant growth and impairs important cellular processes (i.e., photosynthetic electron transport).

Copper compounds are commonly encountered as salts of $\mathrm{Cu}^{2+}$, which often impart blue or green colors, in the past widely used as pigments, therefore. As a native metal it is one of the few metals to occur naturally as an un-compounded mineral and it seems to be the first metal used by man dating back at least 10,000 years in history. A wider usage of copper started in the Copper Age ( $5^{\text {th }}$ millennium BC) and throughout the Antiquity and Middle Age to Nowadays being considered as one of the most important metals.

Copper plays an important function in human diet, because of shared similarities with iron it is crucial for the reddish coloration of hemoglobin in blood. It is essential and indispensable at all higher organisms (plants, animals) especially at cycles and functions of growth and reproduction. The average daily recommended uptake of $\mathrm{Cu}$ should be $0.9 \mathrm{mg}$, falling short of which frequently leads to an increase of cholesterol level and coronary diseases. Copper toxicity in terms of human health can be observed at concentrations higher than $11.0 \mathrm{mg} \mathrm{kg-1}$, affecting functions of main vital organs. A protracted exposition to toxic concentration of $\mathrm{Cu}$ leads to irreparable damages of stomach, kidneys, liver and brain, therefore the daily food should be under permanent sanitary (chemical) control. 


\begin{tabular}{|l|l|}
\hline \multicolumn{1}{|c|}{ Characteristic } & \multicolumn{1}{c|}{ Attribute / Value } \\
\hline Category & transition metal \\
\hline Phase & solid \\
\hline Atomic number & 29 \\
\hline Atomic weight & $63.546 \mathrm{~g} \mathrm{~mol}^{-1}$ \\
\hline Density (liquid density at m.p.) & $8.94 \mathrm{~g} \mathrm{~cm}^{-3}\left(8.02 \mathrm{~g} \mathrm{~cm}^{-3}\right)$ \\
\hline Boiling & $2562^{\circ} \mathrm{C}\left(2835^{\circ} \mathrm{K}\right)$ \\
\hline Heat of fusion & $13.26 \mathrm{~kJ} \mathrm{~mol}^{-1}$ \\
\hline Specific heat capacity & $\left(25^{\circ} \mathrm{C}\right) 24.440 \mathrm{~J} \mathrm{~mol}-1 \cdot \mathrm{K}^{-1}$ \\
\hline Oxidation states & $+1,+2,+3,+4(\mathrm{mildly}$ basic oxide $)$ \\
\hline Crystal structure & face-centred cubic \\
\hline
\end{tabular}

Table 1. Chemical and physical properties of copper $(\mathrm{Cu})$

\section{Copper in past}

Copper has been part of the human civilisations since ancient times up to present days, its first records date back 5,000 and 6,000 years in the past. More specified utilization of copper as metal was achieved in the time of Sumerians and Chaldeans in Mesopotamia, who developed considerable skills in copper handling. Copper fabricated in Mesopotamia was quickly introduced to the the Egyptian Empire where its use flourished thousands of years. These peoples used copper for the fabrication of different jewels, ornaments, but also in the fields of armament and tools. They soon realized that pure copper, because of its softness, is not suitable for shaping tools used in agriculture, cultivation. Later, in the era of the Romans other metals, especially iron and bronze as the main metals in weaponry, gained in importance. In that time copper was first used also for architectural intentions, what can be witnessed on the roof sheathing of the Pantheon.

In Medieval times the use of copper additionally decreased because of the turbulent events in Europe involving the French, Germans, Burgundians, Anglo-Saxons and many more; when bronze had given off its place largely to iron in context of paramount agriculture, but also wars were common in that time. In the context of currency, silver took over the main role, although some copper coins were occasionally hammered in Mercia during the $8^{\text {th }}$ Century.

The copper boom could be linked to immense changes in the time of industrial revolution, when the demand for better raw materials rapidly increased. In the $17^{\text {th }}$ and $18^{\text {th }}$ Centuries massive copper mines and smelting furnaces were exploited and erected to produce several hundreds of tons of pure copper per week.

Nowadays copper presents an important metal, what is undoubtly affirmed by its worldwide annual production of around 5 million tons. Many branches of modern technology use and include copper in their products, especially in the electrical, architectural and chemical industry as well as medicine. The biggest copper sources are located in Chile, USA, Indonesia, Australia and China, where it became the most exported metal.

\section{Copper in horticultural environment}

In the context of metal and environment emphasis has to be laid on a complex system which embraces relations among soil characteristics, plant necessities and human expectations. Copper and its different substances constantly traverse from one to the other stage of this 
system where they are ascribed many roles and have different functions, which is rendered possible with permanent transformation.

\begin{tabular}{|l|l|l|l|l|}
\hline \multirow{2}{*}{ Metal } & \multicolumn{4}{|c|}{ Sediment soils } \\
\cline { 2 - 5 } & Limestone & Sandstone & Slate & Average \\
\hline Chrome (Cr) & $10-11$ & 35 & $90-100$ & 70 \\
\hline Manganese (Mn) & $620-1100$ & $4-60$ & 850 & 650 \\
\hline Cobalt (Co) & $0.1-4$ & 0.3 & $19-20$ & 7 \\
\hline Nickel (Ni) & $7-12$ & $2-9$ & $68-70$ & 40 \\
\hline Copper (Cu) & $5.5-15$ & 30 & $39-50$ & 30 \\
\hline Zinc (Zn) & $20-25$ & $16-30$ & $100-120$ & 50 \\
\hline
\end{tabular}

Table 2. Average content of metals $\left(\mathrm{mg} \mathrm{kg}^{-1}\right)$ in different soil and stoneware types (Ross, 1994; Šajn et al., 1998)

Copper as a microelement effects the characteristics of the soils, that are also its preliminary source, while its content depends on parental matter (Table 2). Copper reaches the soil almost exclusively in divalent form $\left(\mathrm{Cu}^{2+}\right.$ ions) incorporated in minerals but also bound with soil organic matter. Reed \& Martens (1996) reported the specifically adsorption of $\mathrm{Cu}$ to carbonates, soil organic matter, phyllosilicates, and hydrous oxides of $\mathrm{Al}, \mathrm{Fe}$, and $\mathrm{Mn}$. Usually it is dissolved in soil solutions as $\mathrm{Cu}^{2+}$ or as an organic complex adsorbed to inorganic and organic negatively charged groups. The presence of $\mathrm{Cu}^{2+}$ ions in soil solutions decreases with increasing $\mathrm{pH}$, whereas $\mathrm{Cu}$ complexes are less dependent on soil $\mathrm{pH}$. $\mathrm{Cu}^{2+}$, compared to other divalent cations ( $\mathrm{Ni}, \mathrm{Co}, \mathrm{Zn}, \mathrm{Mn}, \mathrm{Mg}$ ), has a strong affinity to soil organic matter, its concentration in soil ranges from $1 \times 10^{-5}$ to $6 \times 10^{-4} \mathrm{~mol} \mathrm{~m}^{-3}$, what is controlled by $\mathrm{Cu}$ adsorption to organic and inorganic soil particles. Because of this the transition of $\mathrm{Cu}$ in deeper soil layers rarely occurs, however it can be promote by soil cultivation (deep ploughing) and by decreasing soil $\mathrm{pH}$ to 5.5-6.5, at which values the mobility of $\mathrm{Cu}$ increases (Fig. 1).

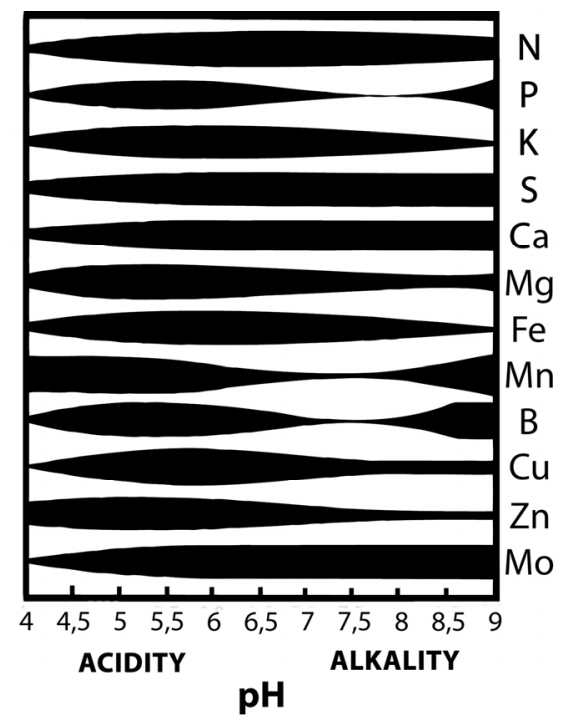

Fig. 1. The mobility of metals according to $\mathrm{pH}$ of soil 
The bounding and bioavailability of $\mathrm{Cu}$ depends also on the concentration of other elements in soil, where an antagonistic effect is observed between $\mathrm{N}, \mathrm{P}$ and $\mathrm{Mo}: \mathrm{Cu}$ and between $\mathrm{Cu}: \mathrm{Zn}$, Mn, while synergism has not been reported yet (Fig. 2).

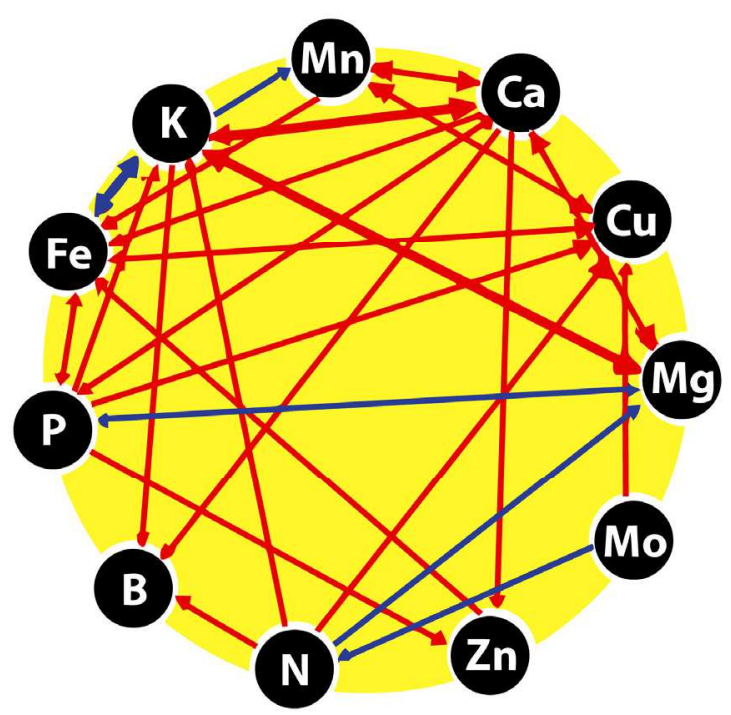

Fig. 2. Synergism (blue) and antagonism (red) among elements in soil

Beside the parental matter of soils the significant "sources" of copper are agriculture (spraying, fertilisation), industry (metallurgy, pharmacy, mining etc.) and cities and roads, which together can be denoted as pollutants. Intensive agricultural practices based on substantial use of copper compounds in fungicides have in the last 200 years lead to copper accumulation in soils, especially in traditional horticultural areas (Fig. 3), like some winegrowing regions in France, Northern Italy, Germany an many more, where copper contents in soils are likely to reach many hundreds ppm. Long time use of $\mathrm{Cu}$ preparations leads to the accumulation of copper, where many data from viticultural area has been already reported (France: Bordeaux $800 \mathrm{mg} \mathrm{kg}^{-1}$, Alsace, Burgundy and Champagne 400 $500 \mathrm{mg} \mathrm{kg}^{-1}$; Italy: Valle d'Aosta $300 \mathrm{mg} \mathrm{kg}^{-1}$, Lombardia $260 \mathrm{mg} \mathrm{kg}^{-1}$, Trentino Alto Adige $161 \mathrm{mg} \mathrm{kg}^{-1}$, Piemonte $90 \mathrm{mg} \mathrm{kg}^{-1}$, Tuscany $34 \mathrm{mg} \mathrm{kg}^{-1}$ etc. (Brun et al., 1998) and Slovenia 5$150 \mathrm{mg} \mathrm{kg}^{-1}$ (Rusjan et al., 2007)). Rusjan et al. (2007) reported that $\mathrm{Cu}$ concentration in soils in horticultural environments with intensive cultivating practices increases with years, especially in the upper soil layers $(<20 \mathrm{~cm})$ reaching more than $150 \mathrm{mg} \mathrm{kg}^{-1}$ after 30 years of permanent $\mathrm{Cu}$ usage. The accumulation of exceeded concentrations of $\mathrm{Cu}$ in soils leads to the perish of flora and fauna in the soils; however the greatest concerns are residuals of $\mathrm{Cu}$ in food (vegetable and fruit).

In the sense of a greater awareness of environmental issues European Union member states and some countries in particular are adopting many regulations to decrease the use of copper compounds in agriculture, where its permitted annual quantity does not exceed $5 \mathrm{~kg}$ of pure $\mathrm{Cu}$ per hectare. An increase of environmentally-sound cultivation practices is frequently mentioned as the most significant reason of excessive $\mathrm{Cu}$ pollution, leading to a 
paradox, as $\mathrm{Cu}$ is in this cultivation practices beside sulphur the only permitted element in pathogen controlling.

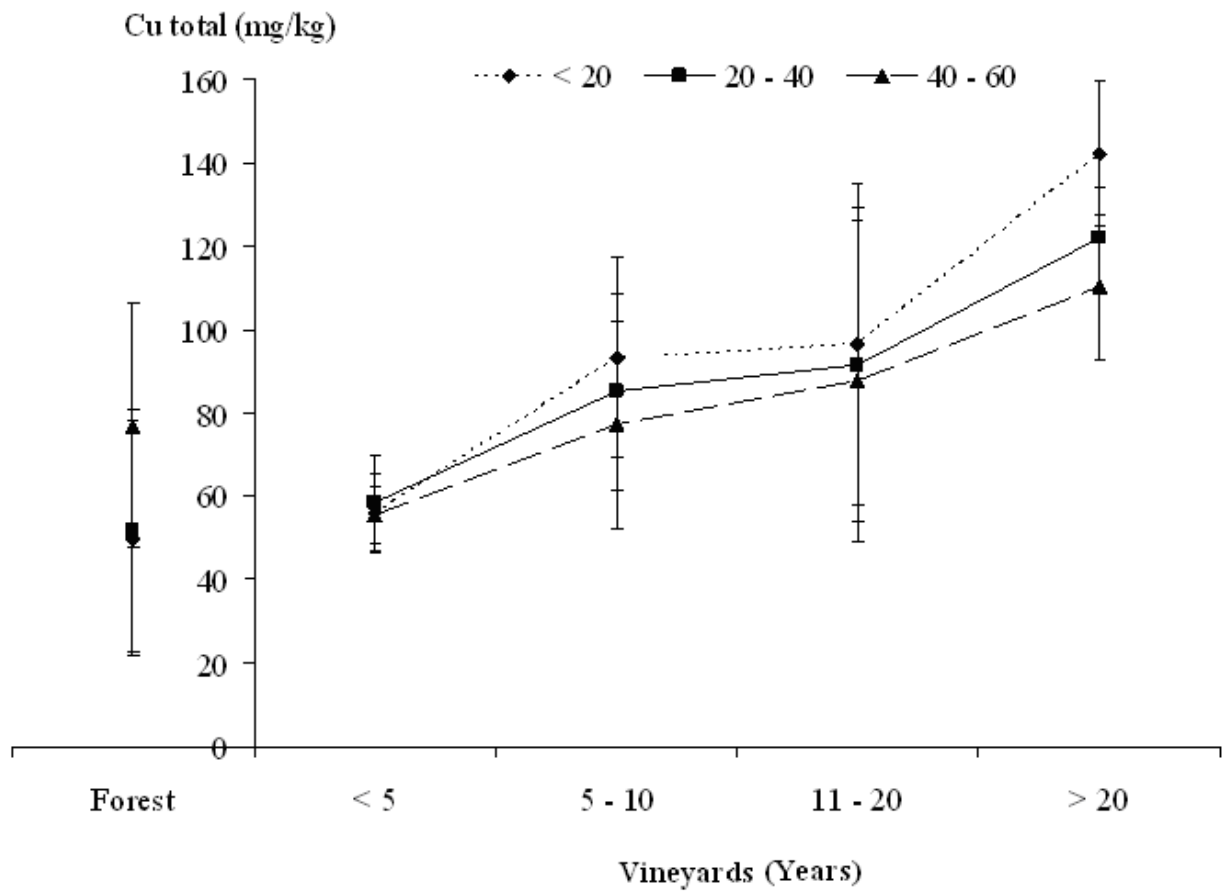

Fig. 3. Differences in total copper accumulation $\left(\mathrm{mg} \mathrm{kg}^{-1}\right)$ according to soil depth $(\mathrm{cm})$ and to vineyards age. Means and standard errors are presented (Rusjan et al., 2007).

\subsection{Copper and horticultural plants}

The essentiality of copper for optimal growth and reproduction in higher plants is largely due to its occurrence as a constituent of several proteins (copper protein/enzyme), which regulate many essential biochemical reactions in plants. Sandmann \& Böger (1983) report three different forms of proteins where copper plays an important component (Cu-proteins): blue proteins (plastocyanin; without oxidase activity) with function in one-electron transfer, non-blue proteins which represents peroxidises and oxidize monophenols to diphenols, and multicopper proteins with at least four $\mathrm{Cu}$-atoms per molecule, which acts as oxidases (ascorbate oxidase and diphenol oxidase). Consequently $\mathrm{Cu}$ plays an essential role at the following physiological and other functions:

a. photosynthesis and respiration: both can be inhibited by $\mathrm{Cu}$ deficiency, as $\mathrm{Cu}$-enzymes catalyse or activate various steps in these processes. $\mathrm{Cu}$ is required for the formation of chlorophyll and other thylakoid constituents - with chlorosis being one of the symptoms of copper deficiency - $\mathrm{Cu}$ is particularly involved in photosynthesis as a component of ribulose-disphosphate carboxylase, while at respiration it is present as the copper enzyme cytochrome-c-oxidase, where its deficiency may reduce respiration rates. 
b. lignifications and phenol metabolism: copper deficiency can significantly reduce the activity of the phenol oxidases which are involved in the lignin synthesis, leading to formations of rather weak tissues and the distortion of leaves and stems. Cu presence affects the synthesis of phenol compounds which inhibit cell elongation. $\mathrm{Cu}$ intensifies oxidation of phenol compounds to chinons, wound healing and pigment formation.

c. regulation of auxins (growth): shortage of auxin is frequently caused by copper deficiency, resulting in a lack of germination. The monophenol compounds control the activity of enzyme auxin oxidase, but diphenols inhibit it.

d. reproduction: deficiency of copper leads to the production of higher polyphenols contents (diphenols) which inhibit the auxin oxidase and consequently the auxin accumulation in anthers. The shortage of auxin causes the formation of a large mass of cellular material, which eventually fills the cavity normally occupied by the pollen grains and consequently renders the pollen grains sterile (Alloway et al., 1985).

The uptake of copper in the form of $\mathrm{Cu}^{2+}$ is done after the metal ion dissociation from the organically complex molecules in soil and it can be enhanced by fungi associated with roots, also known as vesicular-arbuscular mycorrhizae. Research on the interaction between phosphorus and copper contents in soil has already been done; phosphorus improves root growth and thus increases copper absorption, therefore the fertilisation should be adapted at presence or absence of mycorrhizae.

Not only the deficiency of copper contents but also its sufficiency (excess) causes irreversible consequences on plant growth, its cultivation and with that quality (Fig. 4).

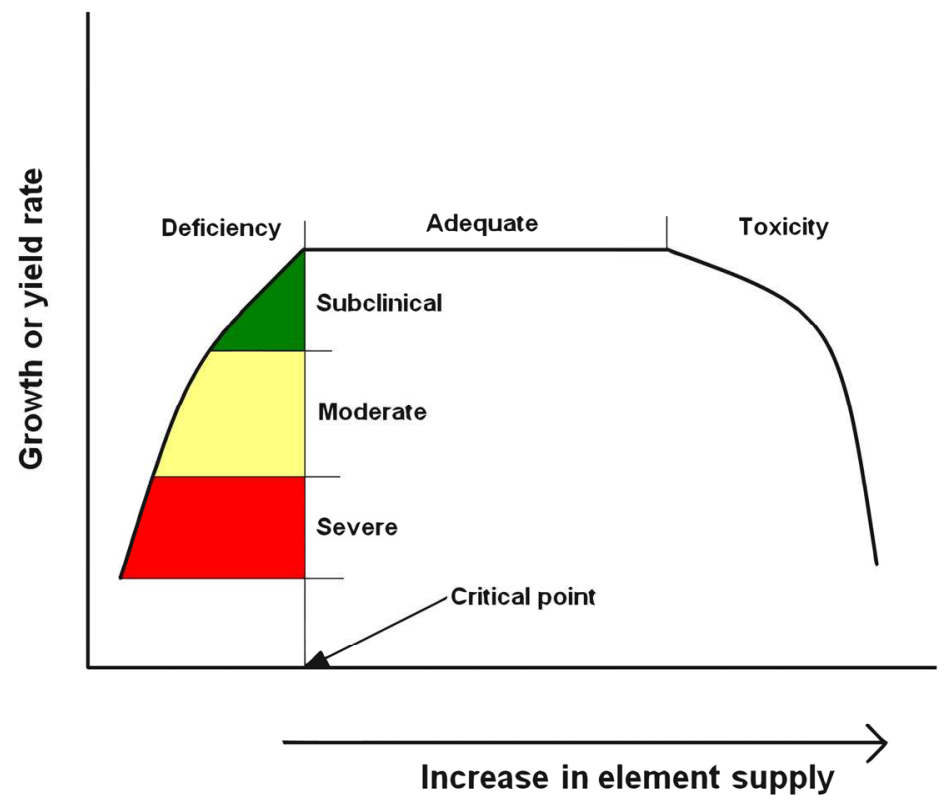

Fig. 4. Effects of copper availability (deficient, sufficient and excessive) on growth and yield of plant 
The toxicity caused by copper is a rare phenomena in horticulture, especially where the control of soil $\mathrm{pH}$ is controlled and regulated. The most frequent symptoms on plants in terms of excessive copper concentrations are inadequate, obstructed shoot and root growth and vigour, whereas also chlorosis frequently appears on leaves. The excess of copper in soil could be controlled with dosing of lime in soils to increase of $\mathrm{pH}$ over 6.5. The effect can be intensified by adding of Fe (iron) because of its antagonism relationship with $\mathrm{Cu}$. The $\mathrm{Cu}$ concentrations over $20 \mathrm{mg} \mathrm{kg}^{-1}$ in dry matter of plant tissues (parts), and over $30 \mathrm{mg} \mathrm{kg}^{-1} \mathrm{in}$ soils can cause toxicity, dependent on plant species, age and part (organ), cultivation practices, environmental conditions and the condition of the plant (infections). The resistance to $\mathrm{Cu}$ toxicity may include immobilization or exclusion of the metal in/from root tissues, formation of complexes among organic acids and proteins, but also adaptation of enzyme mechanisms (Lepp, 1981; Woolhouse and Walker 1981).

\section{Copper in agricultural use: Sustainable horticulture}

First records of the agricultural use of $\mathrm{Cu}$ compounds date back to 1761, when the discovery of the antibacterial effects of copper sulphate preparations used on seed grains set up further standards in cultivation practices for the following decades.

The most important breakthrough of copper use in viticulture though was undoubtedly in 1880, when the French scientist Pierre-Marie Alexis Millardet from the Bordeaux district in France chanced to notice that those vines, which had been daubed with a paste of copper sulphate and lime in water, in order to make the grapes unattractive to passers-bys and as well as animals, appeared less affected by downy mildew. Only five years later in 1885 Millardet announced his discovery to the world, a cure for the dreaded mildew through the application of the mixture of copper sulphate, lime and water, up to the present day called the Bordeaux mixture. Additionally to the Bordeaux mixture, but including copper sulphate and sodium carbonate (soda crystals) the so called Burgundy mixture appeared few years later.

At that time the Bordeaux and Burgundy mixtures became indispensable fungicides against various fungus diseases of plants, where the prevention enhanced with the proper application, means an appropriate timing and correct use of the fungicide. Consequently, as standing for a successful plant protection method up to the present days, many thousands of tons of copper are used annually in agriculture all over the globe.

The days of prosperity of the production of fungicides based on copper compounds were in the middle of $20^{\text {th }}$ century when many different chemical combinations with copper were applied. In the last decades and these days pharmaceutical corporations have been fabricating copper based fungicides in soluble forms of sulphates, oxychlorides, acetates, carbonates, oleates, silicates, ohydroxides etc. Most compounds of copper adopt the oxidation states $\mathrm{Cu}^{+}$and $\mathrm{Cu}^{2+}$, respectively called cuprous and cupric. Their efficiency against fungal and bacterial infections is mostly reflected in their capability to retain on the plant surface, but not by the number of applications or the concentration of the agens in the fungicide. Copper is also biostatic which means that bacteria cannot grow on surfaces treated with it. Copper barriers can range from copper tape made as a slug barrier to more decorative hammered copper sheeting. Any copper that leaches into the soil around the plants is non-toxic and will not adversely affect the plants or people consuming the vegetables and fruits. 
Copper plays an important role not only in pathogen controlling but also in soil fertilization, animal nutrition etc. Excessively long copper use in plant protection but also in terms of fertilisation in modern agriculture lead to copper accumulation in soils, where copper surplus is considered if the soils contain more than two parts per million available copper, bearing in mind the physiological and biochemical needs of the plants. On the other hand the same soil conditions in context of copper deficiency can also affect nutritional statuses of animals and consequently their life expectancy.

\subsection{Copper as fungicide}

First uses of fungicide reach back 400 years ago where simple water solutions (salts) were frequently used for cereal seed treatments. Not earlier than at the beginning of $20^{\text {th }}$ Century more complex organic chemical solutions were introduced (Bordeaux and Burgundy mixture etc.). Nowadays a considerable number of phytochemical companies offer numerous and different classes of fungicides, where copper fungicides according to their antifungal and antibacterial effects play an important role. The efficiency of copper fungicides, particularly aggressive in moist media, is caused by denaturation of protein structures (secondary and tertiary) of fungi and bacteria, and consequently the interruption of their functions. Copper forms compounds in the oxidation states of +1 (cuprous) and +2 (cupric), but trivalent copper in aqueous solution splits rapidly.

Classification of copper fungicide according to chemical structure:

- copper sulphate (cupric sulphate; $\mathrm{CuSO}_{4}$ ),

- copper acetate (cupric acetate; $\left.\mathrm{Cu}(\mathrm{OAc})_{2}\right)$,

- cuprous oxide (copper(I)oxide; $\mathrm{Cu}_{2} \mathrm{O}$ ),

- cupric chloride (copper(II) chloride; $\mathrm{CuCl}_{2}$ ),

- $\quad$ copper oxychloride (copper(II) oxychloride; $\mathrm{CuCl}_{2} \cdot 3 \mathrm{Cu}(\mathrm{OH})_{2}$ ),

- cuprous chloride (copper(I) chloride; $\mathrm{CuCl}$ ),

- $\quad$ cupric nitrate (copper(II) nitrate; $\left.\mathrm{Cu}\left(\mathrm{NO}_{3}\right)_{2}\right)$,

- copper cyanide (copper(I) cyanide; $\mathrm{CuCN}$ ),

- copper soap (solution of copper octanoate),

- copper naphthenate.

\subsubsection{Copper sulphate (cupric sulphate)}

Copper(II) sulphate is a very versatile chemical compound with a wide use in industry but also in horticulture where it exists in a various forms that differs in degree of hydration. Cupric sulphate is the most frequently used form of $\mathrm{Cu}$ in pesticides against many diseases listed in Table 3. It is produced industrially by treating copper metal or its oxides with sulfuric acid, or with placing of copper in a solution of nitric or sulfuric acids as well as in water. The chemical form copper sulphate pentahydrate $\left(\mathrm{CuSO}_{4} \times 5 \mathrm{H}_{2} \mathrm{O}\right)$, a fungicide, mixed with hydrate lime $\left(\mathrm{Ca}(\mathrm{OH})_{2}\right)$, is called Bordeaux mixture or with sodium carbonate $\left(\mathrm{Na}_{2}(\mathrm{CO})_{3}\right)$ Burgundy mixture. Both $\mathrm{Cu}$ solutions are used more than 200 years yet, especially in fungi disease control in horticulture (vineyards, orchards etc.).

Bordeaux mixture is produced by dissolving copper sulphate and hydrated lime in water, mostly in a concentration of $1 \%$; in relation 1:1:100 means $1 \mathrm{~kg}$ of copper sulphate and $1 \mathrm{~kg}$ of hydrated lime is dissolved in 100 litres of water. Copper sulphate contains approx. $25 \%$ 
copper as metal, therefore the content of $\mathrm{Cu}$ in $1 \%$ Bordeaux mixture varies between 0 and 25 $\%$. On the other hand $1 \%$ Burgundy mixture is made by dissolving $1 \mathrm{~kg}$ of copper sulphate in 50 litres of water and separately $125 \mathrm{~kg}$ washing soda (or $0.475 \mathrm{~kg}$ soda ash) in 50 litres of water. After that the soda solution has to be slowly added to the copper sulphate solution with stirring. Both mixtures have been effective in controlling most of the fungi diseases of plants, applied in a time span of 10 to 20 days, depending on fungi species, plant, weather conditions, age and phenological stage of plants etc. According to the manner of $\mathrm{Cu}$ use it is important that first spraying is done before the diseases is expected and continued at regular intervals throughout the susceptible period. The protective coating of $\mathrm{Cu}$ mixtures prevents spores germination and consequently their damages caused by penetration through tissues of unprotected parts of plants. An effective spraying scheme has to ensure permanent copper coating over susceptible plant parts, what demands accuracy of the timing of the spraying, especially at precipitation $(>30 \mathrm{~mm})$ and at intensive fruit growing (fruit enlargement).

\begin{tabular}{|c|c|}
\hline Plant & Disease and Pathogen \\
\hline \multicolumn{2}{|l|}{ Fruits } \\
\hline \multirow{4}{*}{ Almond } & Blossom wilt (Sclerotinia laxa; Sclerotinia fructigena) \\
\hline & Leaf curl (Taphrina deformans) \\
\hline & Rust (Puccinia pruni-spinosae) \\
\hline & Shot hole (Clasterosporium carpophilum) \\
\hline \multirow{8}{*}{ Apple } & Bitter rot (Glomerella cingulata) \\
\hline & Black rot (Physalospora obtusa) \\
\hline & Blossom wilt (Sclerotinia laxa) \\
\hline & Blotch (Phyllosticta solitaria) \\
\hline & Canker (Nectria galligena) \\
\hline & Fireblight (Erwinia amylovora) \\
\hline & Pink disease (Corticium salmonicolor) \\
\hline & Scab (Venturia inaequalis) \\
\hline \multirow{3}{*}{ Apricot } & Blossom wilt (Sclerotinia laxa and Sclerotinia fructigena) \\
\hline & Rust (Puccinia pruni-spinosae) \\
\hline & Shot hole (Clasterosporium carpophilum) \\
\hline \multirow{4}{*}{ Avocado } & Anthracnose (Black spot) (Glomerella cingulata) \\
\hline & Bacterial rot (Pseudomonas syringae) \\
\hline & Fruit spot (Cercospora purpurea) \\
\hline & Scab (Sphaceloma perseae) \\
\hline \multirow{3}{*}{ Banana } & Black rot (Die back) (Botryodiplodia theobromae) \\
\hline & Helminthosporiosis (Helminthosporium sp.) \\
\hline & Sigatoka disease (Leaf spot) (Mycosphaerella musicola) \\
\hline Blackberry & Cane spot (Elsinoe veneta) \\
\hline \multirow{3}{*}{ Blueberry } & Fruit rot (Sclerotinia vaccinii-corymbosi) \\
\hline & Leaf rust (Pucciniastrum myrtilli) \\
\hline & Powdery mildew (Microsphaera alni var. vaccinii) \\
\hline
\end{tabular}




\begin{tabular}{|c|c|}
\hline Plant & Disease and Pathogen \\
\hline \multirow{7}{*}{ Cherry } & Bacterial canker (Pseudomonas mors-prunorum) \\
\hline & Bitter rot (Glomerella cingulata) \\
\hline & Brown rot (Blossom wilt) (Sclerotinia laxa and Sclerotinia fructigena) \\
\hline & Leaf scorch (Gnomonia erythrostoma) \\
\hline & Leaf spot (Coccomyces hiemalis) \\
\hline & Scab (Venturia cerasi) \\
\hline & Shot hole (Clasterosporium carpophilum) \\
\hline \multirow{2}{*}{ Chestnut } & Blight (Endothia parasitica) \\
\hline & Ink disease (Phytophthora cambivora) \\
\hline \multirow{12}{*}{ Citrus } & Anthracnose (Wither tip) (Gloeosporium limetticola) \\
\hline & Black pit (Pseudomonas syringae) \\
\hline & Black spot (Phoma citricarpa) \\
\hline & Brown rot (Phytophthora spp.) \\
\hline & Canker (Xanthomonas citri) \\
\hline & Mal secco (Deuterophoma tracheiphila) \\
\hline & Melanose (Diaporthe citri) \\
\hline & Scab (Elsinoe fawcetti) \\
\hline & Septoria spot (Septoria depressa) \\
\hline & Sooty blotch (Leptothyrium pomi) \\
\hline & Sooty mould (Aithaloderma citri) \\
\hline & Thread blight (Corticium koleroga) \\
\hline \multirow{2}{*}{ Currant (Ribes) } & Leaf spot (Mycosphaerella grossulariae and Mycosphaerella ribis) \\
\hline & Leaf spot (Pseudopeziza ribis) \\
\hline \multirow{5}{*}{ Fig } & Blight (Phizoctonia microsclerotia) \\
\hline & Canker (Phomopsis cinerescens) \\
\hline & Leaf fall and Fruit rot (Cercospora bolleana) \\
\hline & Rust (Cerotelium fici) \\
\hline & Thread blight (Corticium koleroga) \\
\hline Fruit trees & Crown gall (Bacterium tumefaciens) \\
\hline \multirow{4}{*}{ Gooseberry } & American mildew (Sphaerotheca mors-uvae) \\
\hline & Cluster cup rust (Puccinia pringshemiana) \\
\hline & Die back (Botrytis cinerea) \\
\hline & Leaf spot (Mycosphaerella grossulariae) \\
\hline \multirow{6}{*}{ Mango } & Anthracnose (Colletotrichum gloeosporioides) \\
\hline & Anthracnose (Gloeosporium mangiferae) \\
\hline & Bacterial black spot (Erwinia mangiferae) \\
\hline & Powdery mildew (Oidium mangiferae) \\
\hline & Red rust (Cephaleuros virescens) \\
\hline & Scab (Elsinoe mangiferae) \\
\hline
\end{tabular}




\begin{tabular}{|c|c|}
\hline Plant & Disease and Pathogen \\
\hline \multirow{4}{*}{ Nectarine } & Blossom wilt (Sclerotinia laxa and Sclerotinia fructigena) \\
\hline & Leaf curl (Taphrina deformans) \\
\hline & Rust (Puccinia pruni-spinosae) \\
\hline & Shot hole (Clasterosporium carpophilum) \\
\hline Olive & Leaf spot (Cycloconium oleaginum) \\
\hline \multirow{2}{*}{ Passion fruit } & Brown spot (Alternaria passiflorae) \\
\hline & Grease spot (Pseudomonas passiflorae) \\
\hline \multirow{4}{*}{ Peach } & Blossom wilt (Sclerotinia laxa and Sclerotinia fructigena) \\
\hline & Leaf curl (Taphrina deformans) \\
\hline & Rust (Puccinia pruni-spinosae) \\
\hline & Shot hole (Clasterosporium carpophilum) \\
\hline \multirow{6}{*}{ Pear } & Bitter rot (Glomerella cingulata) \\
\hline & Firebiiglit (Erwinia amylovora) \\
\hline & Leaf spot (Leaf speck) (Mycosphaerella sentina) \\
\hline & Scab (Venturia pirina) \\
\hline & Scab (America) (Cladosporium effusum) \\
\hline & Thread blight (Corticium koleroga) \\
\hline \multirow{9}{*}{ Plum } & Bacterial canker (Pseudomonas mors-prunorum) \\
\hline & Bacterial spot (Xanthomonas pruni) \\
\hline & Black rot (Dibotryon morbosum) \\
\hline & Blossom wilt (Sclerotinia laxa) \\
\hline & Brown rot (Sclerotinia fructigena) \\
\hline & Rust (Puccinia pruni-spinosae) \\
\hline & Shot hole (Clasterosporium carpophilum) \\
\hline & Watery rot (Pocket plums) (Taphrina pruni) \\
\hline & Wilt (Pseudomonas prunicola) \\
\hline \multirow{3}{*}{ Raspberry } & Cane spot (Anthracnose) (Elsinoe veneta) \\
\hline & Cane wilt (Leptosphaeria coniothyrium) \\
\hline & Spur blight (Didymella applanata) \\
\hline Strawberry & Leaf spot (Mycosphaerella fragariae) \\
\hline \multirow{10}{*}{ Grapevine } & "Coitre" (Coniothyrium diplodiella) \\
\hline & Angular leaf spot (Mycosphaerella angulata) \\
\hline & Anthracnose (Elsinoe ampelina) \\
\hline & Crown gall (Bacterium tumefaciens) \\
\hline & Bitter rot (Melanconium fuligineum) \\
\hline & Black rot (Guignardia bidwellii) \\
\hline & Downy mildew (Plasmopara viticola) \\
\hline & Leaf spot (Isariopsis fuckelli) \\
\hline & Powdery mildew (Uncinula necator) \\
\hline & Totbrenner (Pseudopeziza tracheiphila) \\
\hline
\end{tabular}




\begin{tabular}{|c|c|}
\hline Plant & Disease and Pathogen \\
\hline Vine (Sultana) & Sooty dew (Exosporium sultanae) \\
\hline \multirow{4}{*}{ Walnut } & Anthracnose (Blotch) (Gnomonia leptostyla) \\
\hline & Downy leaf spot (Microstroma juglandis) \\
\hline & Blight (Xanthomonas juglandis) \\
\hline & Ring spot (Ascochyta juglandis) \\
\hline \multicolumn{2}{|l|}{ Vegetable and others } \\
\hline Artichoke (Globe) & Ramularia cynarae \\
\hline Asparagus & Rust (Puccinia asparagi) \\
\hline \multirow{3}{*}{ Bean (Broad) } & Chocolate spot (Botrytis cinerea) \\
\hline & Leaf spot (Asochyta pisi) \\
\hline & Rust (Uromyces fabae) \\
\hline \multirow{5}{*}{ Bean (French and Runner) } & Anthracnose (Colletotrichum lindemuthianum) \\
\hline & Common blight (Xanthomonas phaseoli) \\
\hline & Halo blight (Pseudomonas medicaginis var. phaseolicola) \\
\hline & Powdery mildew (Erysiphe polygoni) \\
\hline & Rust (Uromyces appendiculatus) \\
\hline \multirow{4}{*}{ Brassicas } & Black leg (Canker) (Phoma lingam) \\
\hline & Black rot (Xanthomonas campestris) \\
\hline & Damping off (Oipidium brassicae) \\
\hline & Downy mildew (Peronospora parasitica) \\
\hline \multirow{3}{*}{ Carrot } & Bacterial soft rot (Bacterium carotovorum) \\
\hline & Blight (Alternaria dauci) \\
\hline & Leaf spot (Cercospora carotae) \\
\hline \multirow{8}{*}{ Cucurbits } & Anthracnose (Colletotrichum lagenarium) \\
\hline & Black rot (Mycosphaerella citrullina) \\
\hline & Downy mildew (Pseudoperonospora cubensis) \\
\hline & Leaf blight (Alternaria cucumerina) \\
\hline & Powdery mildew (Erysiphe cichoracearum) \\
\hline & Stem end rot (Physalospora rhodina) \\
\hline & Wet rot (Choanephora cucurbitarum) \\
\hline & Wilt (Erwinia tracheiphila) \\
\hline \multirow{4}{*}{ Grasses } & Brown patch of lawns (Rhizoctonia and Holminthosporium spp.) \\
\hline & Red thread (Corticium fusiforme) \\
\hline & Snow mould (Calonectria graminicola) \\
\hline & Stripe smut (Ustilago striiformis) \\
\hline
\end{tabular}




\begin{tabular}{|c|c|}
\hline Plant & Disease and Pathogen \\
\hline \multirow{2}{*}{ Lettuce } & Downy mildew (Bremia lactucae) \\
\hline & Ring spot (Marssonina panattoniana) \\
\hline Onion & Downy mildew (Peronospora destructor) \\
\hline Persimmon & Canker (Phomopsis diospyri) \\
\hline \multirow{4}{*}{ Potato } & Blight (Late blight) (Phytophthora infestans) \\
\hline & Dry rot (Sclerotium rolfsii) \\
\hline & Early blight (Alternaria solani) \\
\hline & Grey mould (Botrytis cinerea) \\
\hline \multirow{5}{*}{ Rose } & Black spot (Diplocarpon rosae) \\
\hline & Downy mildew (Peronospora sparsa) \\
\hline & Leaf spot (Anthracnose) (Sphaceloma rosarum) \\
\hline & Mildew (Sphaerotheca pannosa) \\
\hline & Rust (Phragmidium mucronatum) \\
\hline \multirow{2}{*}{ Spinach } & Leaf spot (Heterosporium variabile) \\
\hline & Downy mildew (Peronospora effusa) \\
\hline \multirow{2}{*}{ Sugar beet } & Leaf spot (Cercospora beticola) \\
\hline & Downy mildew (Peronospora schactii) \\
\hline \multirow{2}{*}{ Sunflower } & Rust (Puccinia helianthi) \\
\hline & Wilt (Sclerotinia sclerotiorum) \\
\hline Sweet potato & Wilt (Fusarium spp.) \\
\hline \multirow{4}{*}{ Tea } & Black rot (Die back) (Botryodiplodia theobromae) \\
\hline & Blister blight (Exobasidium vexans) \\
\hline & Grey blight (Pestalotia theae) \\
\hline & Red rust (Cephaleuros niycoidea) \\
\hline \multirow{11}{*}{ Tomato } & Anthracnose (Colletotrichum phomoides) \\
\hline & Bacterial spot (Xanthomonas vesicatoria) \\
\hline & Blight (Late blight) (Phytophthora infestans) \\
\hline & Early blight (Alternaria solani) \\
\hline & Foot rot (Phytophthora cryptogea) \\
\hline & Fruit rot (Didymella lycopersici) \\
\hline & Fruit rot (Phytophthora capsici) \\
\hline & Grey leaf spot (Stemphylium solani) \\
\hline & Leaf mould (Cladosporium fulvum) \\
\hline & Leaf spot (Septoria lycopersici) \\
\hline & Mildew (Leveilluia taurica) \\
\hline
\end{tabular}

Table 3. List of diseases and pathogens at some horticultural plants suitable to control with copper fungicides 


\subsubsection{Copper acetates}

Copper(II) acetate is also known as cupric acetate with the chemical formula $\mathrm{Cu}(\mathrm{OAc})_{2}$, where OAc- stands for acetate $\left(\mathrm{CH}_{3} \mathrm{CO}_{2}^{-}\right)$. Since ancient times copper acetates of some form have been used as fungicides (greenish colour), whereas nowadays more frequently as reagents for syntheses of many inorganic and organic compounds. Copper acetate is odourless and efflorescent. It is soluble in alcohol and slightly soluble in ether and glycerol. The commercially available copper acetates are these in hydrated forms $\left(\mathrm{Cu}\left(\mathrm{C}_{2} \mathrm{H}_{3} \mathrm{O}_{2}\right)_{2} \mathrm{H}_{2} \mathrm{O}\right)$; $\mathrm{Mr}=199.67 \mathrm{~g} \mathrm{~mol}^{-1}$ ) which contain one molecule of water for each atom of $\mathrm{Cu}$. The production of copper acetates first appeared in France, where the term of "verdigris" (verte grez) was applied. At grape remaking and wine production copper metal sheets were used, and when the surface of copper sheets exposed to the air for some days, they had become coated with verdigris, which were removed, and then replaced. The obtained product was known as blue verdigris and in a concentration of $1 \mathrm{~kg}$ of basic copper acetate in 500 litres of water; it was used as a fungicide. It contains approx. $32 \%$ of copper and crystallises with 1 mol crystal water. Nowadays it is prepared by dissolving cupric oxide or a copper carbonate in acetic acid; however it can be produced also by treating a copper sulphate solution with lead acetate or by the reaction of acetic acid and copper with subsequent crystallization.

Until the 19th century, verdigris coincidentally happened to be the most vibrant green pigment available and was therefore frequently used in painting. Copper acetates of different chemical compositions make up pigments, colours from green to green-blue, bluegreen, and finally blue. Reactions with copper acetate vary among substances such as the following: copper acetates dissolve in mineral acid, alkalis convert them into blue copper hydroxide, oils, resins and proteins react to form green transparent copper oleates, resinates, and proteinates.

Neutral Verdigris is neutral copper acetate which occurs when basic acetates are dissolved in acetic acid, or when basic verdigris is ground up with strong acidic acid. Basic verdigris forms from the combination of air, water vapour, acetic acid vapour, and copper or copper alloy mix. It forms a solid of blue, or blue-green material. It is often made up of fine needles. The chemical formula for basic verdigris can include all of the following (Kühn, 1997):

$$
\begin{gathered}
{\left[\mathrm{Cu}\left(\mathrm{CH}_{3} \mathrm{COO}_{2}\right]_{2} \cdot \mathrm{Cu}(\mathrm{OH})_{2} \cdot 5 \mathrm{H}_{2} \mathrm{O}\right. \text { (blue) }} \\
\mathrm{Cu}\left(\mathrm{CH}_{3} \mathrm{COO}\right)_{2} \cdot \mathrm{Cu}(\mathrm{OH})_{2} \cdot 5 \mathrm{H}_{2} \mathrm{O} \text { (blue) } \\
\mathrm{Cu}\left(\mathrm{CH}_{3} \mathrm{COO}\right)_{2} \cdot\left[\mathrm{Cu}(\mathrm{OH})_{2}\right]_{2} \text { (blue) } \\
\mathrm{Cu}\left(\mathrm{CH}_{3} \mathrm{COO}\right)_{2} \cdot\left[\mathrm{Cu}(\mathrm{OH})_{2}\right]_{3} \cdot 2 \mathrm{H}_{2} \mathrm{O} \text { (green) }
\end{gathered}
$$

Synonyms of cupric acetate are acetate cuivrique (DOT French); acetato cuprico (DOT Spanish); acetic acid cupric salt; acetic acid, cupric salt; copper acetate; copper acetate $\left(\mathrm{Cu}\left(\mathrm{C}_{2} \mathrm{H}_{3} \mathrm{O}_{2}\right)_{2}\right)$; copper acetate $\left(\mathrm{Cu}\left(\mathrm{MCO}_{2}\right)_{2}\right)$; copper acetate $\left(\mathrm{Cu}(\mathrm{OAc})_{2}\right)$; copper diacetate; copper (II) acetate; copper (II) diacetate; copper (II) acetate; crystallized verdigris; crystals of venus; cupric acetate monoydrate; cupric diacetate; neytral verdigris; and venus copper.

\subsubsection{Cuprous oxide}

Cuprous oxide is an inorganic compound of two known forms: copper(I) oxide $\left(\mathrm{Cu}_{2} \mathrm{O}\right.$; $\left.\mathrm{Mr}=143.08 \mathrm{~g} \mathrm{~mol}^{-1}\right)$, in nature present as cuprite, dark red crystals or granular powder, formed on copper by heat, and cupric oxide copper(II) oxide $\left(\mathrm{CuO} ; \mathrm{Mr}=79.55 \mathrm{~g} \mathrm{~mol}^{-1}\right)$, 
a black-brown crystal or amorphous powder. It is used in making fibres and ceramics and for welding fluxes. $\mathrm{Cu}_{2} \mathrm{O}$ presents one of the principal oxides of copper. The most common preparation of cuprous oxide is by oxidation of copper metal $4 \mathrm{Cu}+\mathrm{O}_{2} \rightarrow 2 \mathrm{Cu}_{2} \mathrm{O}$; $2 \mathrm{Cu}+\mathrm{O}_{2} \rightarrow 2 \mathrm{CuO}$, commercially however also by reduction of copper(II) solutions with sulfur dioxide, the final product of which is reddish mineral cuprite. Cuprous oxide is commonly used as a pigment (colouring of porcelain and glass), a fungicide (seed dressings) and an antirust protection agent for marine paints. Available on the market are copper(II) oxides with a copper content of around $78 \%$.

Synonyms of cuprous oxide are yellow cuprocide; red copper oxide; dicopper monoxide; dicopper oxide; brown copper oxide; copper hemioxide; Copper nordox; copper protoxide; copper suboxide; cuprite; cuprocide; fungimar; dikupferoxid (German); óxido de dicobre (Spanish); oxyde de dicuivre (French).

\subsubsection{Cupric chloride}

Copper(II) chloride is a light brown solid chemical compound with the formula $\mathrm{CuCl}_{2}$ and has the potential of slowly absorbing moisture and forming a blue-green dihydrate., The aqueous solution prepared from copper(II) chloride contains a range of copper(II) complexes depending on concentration, temperature, and the presence of additional chloride ions. Copper(II) chloride occurs as a very rare mineral in nature, tolbachite and the dihydrate eriochalcite, more common however are mixed oxyhydroxide-chlorides, like atacamite $\mathrm{Cu}_{2}(\mathrm{OH})_{3} \mathrm{Cl}$. There are few preparations of cupric chloride known, used as fungicide in agriculture as well:

a. chlorination of copper: $\mathrm{Cu}+\mathrm{Cl}_{2}+2 \mathrm{H}_{2} \mathrm{O} \rightarrow \mathrm{CuCl}_{2}\left(\mathrm{H}_{2} \mathrm{O}\right)_{2}$,

b. treatment of $\mathrm{Cu}$ hydroxide, oxide or $\mathrm{Cu}(\mathrm{II})$ carbonate with hydrochloric acid,

c. anhydrous $\mathrm{CuCl}_{2}$ prepared directly by the union of copper and chlorine and

d. by crystallization of torrid dilute hydrochloric acid, cooling in $\mathrm{CaCl}_{2}$-ice bath

$\mathrm{CuCl}_{2}$ is a yellowish to brown, deliquescent powder soluble in water, alcohol and ammonium chloride, used as a mordant in dyeing and printing textiles. $\mathrm{CuCl}$ consists of fine grey-black pearls with size of a few hundred $\mu \mathrm{m}$ and a copper content of $64 \%$. Copper(II) chloride dihydrate $\left(\mathrm{CuCl}_{2} \times 2 \mathrm{H}_{2} \mathrm{O}\right)$ is built up of blue-green crystals, soluble in water and has a copper content of approx. $37 \%$. Anhydrous copper(II) chloride is a brown crystal powder, soluble in water and highly hygroscopic, with a copper content of approx. $47 \%$.

Synonyms of cupric chloride; copper(II) chloride; dichlorocopper, Kupferdichlorid (German); dicloruro de cobre (Spanish); dichlorure de cuivre (French).

\subsubsection{Cuprous chloride}

Copper(I) chloride, known also as lower chloride of copper with the formula $\mathrm{CuCl}$ $\left(\mathrm{Mr}=99.03 \mathrm{~g} \mathrm{~mol}^{-1}\right)$ or $\mathrm{Cu}_{2} \mathrm{Cl}_{2}\left(\mathrm{Mr}=198.05 \mathrm{~g} \mathrm{~mol}^{-1}\right)$, is a white solid substance partially soluble in water, but totally in concentrated hydrochloric acid. In middle of $17^{\text {th }}$ century cuprous chloride was first produced by Robert Boyle from mercury(II) chloride and metal $\mathrm{Cu}: \mathrm{HgCl}_{2}+2 \mathrm{Cu} \rightarrow 2 \mathrm{CuCl}+\mathrm{Hg}$. Later Proust J.L. prepared $\mathrm{CuCl}$ by heating $\mathrm{CuCl}_{2}$ at red heat in absence of air, causing it to lose half of its combined chlorine, followed by removing residual $\mathrm{CuCl}_{2}$ by rinsing with water, and by the application which was widely used for heating and lighting. During the $19^{\text {th }}$ and early $20^{\text {th }}$ Centuries the acidic solution of $\mathrm{CuCl}$ 
was formerly used for analysis of carbon monoxide content in gases, for example in Hempel's gas apparatus. The moist powder's exposure to air and sunlight, results in a color change to yellow, violet and blue-black. The main use of copper(I) chloride is in phytochemistry as a precursor to the fungicide copper oxychloride (dicopper chloride trihydroxide; $\mathrm{Cu}_{2}(\mathrm{OH})_{3} \mathrm{Cl}$ ) green crystalline solid, largely stable in neutral media, but decomposes by warming in alkaline media, yielding oxides, virtually insoluble in water and organic solvents, soluble in mineral acids yielding the corresponding copper salts. For this purpose aqueous copper(I) chloride is generated by comproportionation and later airoxidized:

$$
\begin{gathered}
\mathrm{Cu}+\mathrm{CuCl}_{2} \rightarrow 2 \mathrm{CuCl} \\
6 \mathrm{CuCl}+3 / 2 \mathrm{O}_{2}+3 \mathrm{H}_{2} \mathrm{O} \rightarrow 2 \mathrm{Cu}_{3} \mathrm{Cl}_{2}(\mathrm{OH})_{4}+\mathrm{CuCl}_{2}
\end{gathered}
$$

Synonyms of cuprous chloride are copper chloride; copper monochloride; chlorid medny; copper(1+) chloride; cuprous monochloride; dicopper dichloride; Kupferchlorid (German); cloruro de cobre (Spanish); chlorure de cuivre (French).

\subsubsection{Copper oxychloride}

Copper oxychloride is a basic copper chloride with the formula $\mathrm{CuCl}_{2} \times 3 \mathrm{Cu}(\mathrm{OH})_{2}$, a green powder used as a blue colour agent and as a fungicide (form as powder, wettable powders and pastes) that controls a wide range of fungal and bacterial diseases of fruits, vegetables and ornamentals. Usually it is manufactured either by the reaction of hydrochloric acid and copper metal or by the air oxidation of cuprous chloride suspensions. It usually contains approx. $57 \%$ of copper and is not soluble in water, but in various acids. Beside its use as fungicide (Table 4) it is also applied as a compound of herbicides and insecticides.

Synonyms of copper oxychloride are copper chloride mixture with copper oxide, hydrate; dicopper chloride trihydroxide; cupric oxide chloride; copper(II) oxychloride; copper oxychloride; vitigran blue; Dikupferchloridtrihydroxid (German); trihidroxicloruro de dicobre (Spanish); trihydroxychlorure de dicuivre (French); tribasic copper chloride; copper chloroxide; copper(II) chloride hydroxide.

\subsubsection{Cupric nitrate}

Copper(II) nitrate is also known as copper nitrate, its chemical formula is $\mathrm{Cu}\left(\mathrm{NO}_{3}\right)_{2}$ $\left(\mathrm{Mr}=232.60 \mathrm{~g} \mathrm{~mol}^{-1}\right)$. In anhydrous form it is blue coloured, in crystalline and it is used for formulation of fungicides and herbicides. The production of cupric nitrate follows the processes underneath:
a. treating metal $\mathrm{Cu}$ with $\mathrm{N}_{2} \mathrm{O}_{4}\left(\mathrm{Cu}+2 \mathrm{~N}_{2} \mathrm{O}_{4} \rightarrow \mathrm{Cu}\left(\mathrm{NO}_{3}\right)_{2}+2 \mathrm{NO}\right)$,
b. hydrolysis of the anhydrous material (preparation of copper nitrate hydrate) and
c. treating copper metal with an aqueous solution of silver nitrate or concentrated nitric acid $\left(\mathrm{Cu}+4 \mathrm{HNO}_{3} \rightarrow \mathrm{Cu}\left(\mathrm{NO}_{3}\right)_{2}+2 \mathrm{H}_{2} \mathrm{O}+2 \mathrm{NO}_{2}\right)$

Copper nitrate hydrate $\left(\mathrm{Cu}\left(\mathrm{NO}_{3}\right)_{2} \mathrm{nH}_{2} \mathrm{O}\right)$ appears either as a green powder or blue crystallised, it is soluble in water, used in electroplating copper on iron, as a catalyst and nitrating agent in organic reactions, fungicides and wood preservatives and as a pigment for ceramics. Copper(II) nitrate trihydrate $\left(\mathrm{Cu}\left(\mathrm{NO}_{3}\right)_{2} \times 3 \mathrm{H}_{2} \mathrm{O}\right)$ is a frequent crystalline product with a copper content of around $26 \%$, consisting of rather large blue-green crystals. 


\begin{tabular}{|c|c|c|}
\hline Plant & Disease & Application \\
\hline $\begin{array}{l}\text { Pipfruit, } \\
\text { Stonefruit }\end{array}$ & $\begin{array}{l}\text { Black spot, Fire blight, } \\
\text { European canker, Leaf } \\
\text { curl, Shot hole (die-back), } \\
\text { Bacterial spot, Stonefruit } \\
\text { blast }\end{array}$ & $\begin{array}{l}\text { Bud burst and green tip (Sept.), leaf } \\
\text { fall (May) and winter dormancy. }\end{array}$ \\
\hline $\begin{array}{l}\text { Citrus, } \\
\text { Passionfruit }\end{array}$ & $\begin{array}{l}\text { Verrucosis, Brown rot, } \\
\text { Melanose, Black spot, } \\
\text { Phytophthora blight }\end{array}$ & $\begin{array}{l}\text { Petal fall and at 3-4 weekly intervals } \\
\text { until harvest. }\end{array}$ \\
\hline $\begin{array}{l}\text { Grapes, } \\
\text { Berryfruits }\end{array}$ & $\begin{array}{l}\text { Downy mildew, Leaf } \\
\text { spots, Rust }\end{array}$ & $\begin{array}{l}\text { Bud burst to harvest at } 14 \text { day } \\
\text { intervals. Further applications } \\
\text { would be necessary if conditions } \\
\text { favour infection. }\end{array}$ \\
\hline $\begin{array}{l}\text { Roses, } \\
\text { Ornamentals }\end{array}$ & $\begin{array}{l}\text { Black spot, Downy } \\
\text { mildew, Leaf spots, Fire } \\
\text { blight }\end{array}$ & $\begin{array}{l}\text { Bud burst and green tip (Sept), leaf } \\
\text { fall (May) and winter dormancy. }\end{array}$ \\
\hline $\begin{array}{l}\text { Beans, } \\
\text { Peas }\end{array}$ & $\begin{array}{l}\text { Seed rots, Anthracnose, } \\
\text { Bacterial brown spot, } \\
\text { Rust, Rust blight }\end{array}$ & $\begin{array}{l}\text { Dust seed thoroughly prior to } \\
\text { sowing. Bud burst and green tip. }\end{array}$ \\
\hline $\begin{array}{l}\text { Broccoli, } \\
\text { Carrots, } \\
\text { Cucumber, } \\
\text { Lettuce, } \\
\text { Zucchini } \\
\end{array}$ & $\begin{array}{l}\text { Anthracnose, Leaf spots, } \\
\text { Early and late blight, } \\
\text { Bacterial blight }\end{array}$ & $\begin{array}{l}\text { Apply when disease first appears. } \\
\text { Repeat at } 7 \text { - } 14 \text { day intervals, } \\
\text { whilst conditions favour infection. }\end{array}$ \\
\hline Tomato & $\begin{array}{l}\text { Anthraconse, Bacterial } \\
\text { speck, Bacterial spot, Late } \\
\text { blight, Septoria leaf spot }\end{array}$ & $\begin{array}{l}\text { Apply when disease first appears. } \\
\text { Repeat at } 7-14 \text { day intervals, } \\
\text { whilst conditions favour infection. }\end{array}$ \\
\hline Walnut & Walnut Blight & $\begin{array}{l}\text { Apply at least three sprays at } 7-10 \\
\text { day intervals. Further applications } \\
\text { would be necessary if conditions } \\
\text { favour infection. }\end{array}$ \\
\hline $\begin{array}{l}\text { Ornamentals } \\
\text { (flowers and shrubs) }\end{array}$ & $\begin{array}{l}\text { Fungal leaf spots, } \\
\text { Downy Mildew }\end{array}$ & $\begin{array}{l}\text { Apply when disease first appears. } \\
\text { Repeat at } 7-14 \text { day intervals as } \\
\text { required. Small scale phytotoxicity } \\
\text { tests are recommended as some } \\
\text { varieties may be sensitive under } \\
\text { certain conditions. }\end{array}$ \\
\hline Red beet & $\begin{array}{l}\text { Downy Mildew, } \\
\text { Rust }\end{array}$ & $\begin{array}{l}\text { Apply at } 10 \text { to } 14 \text { day intervals, } \\
\text { from the seedling stage until } \\
\text { maturity, while conditions allow } \\
\text { infection. }\end{array}$ \\
\hline Strawberries & $\begin{array}{l}\text { Leaf Spot, } \\
\text { Leaf Scorch }\end{array}$ & $\begin{array}{l}\text { Apply at } 10-14 \text { day intervals in } \\
\text { wet weather or if conditions favour } \\
\text { infection. }\end{array}$ \\
\hline
\end{tabular}

Table 4 . The plants and diseases where the application of copper oxychloride was effective 
Synonyms of cupric nitrare are cupric nitrate hemipentahydrate; nitric acid, copper (II) salt, hydrate (2:5); copper II nitrate hemihydrate; Kupferdinitrat (German); dinitrato de cobre (Spanish); dinitrate de cuivre (French).

\subsubsection{Copper cyanide}

Copper(I) cyanide as an inorganic compound and has the chemical formula $\mathrm{CuCN}$, due to the presence of $\mathrm{Cu}(\mathrm{II})$ impurities it can be green, it is a useful in electroplating copper, furthermore it can also be applied as a reagent in the preparation of nitriles. It is insoluble in water but rapidly dissolves in solutions containing $\mathrm{CN}-$ to form $\left[\mathrm{Cu}(\mathrm{CN})_{3}\right]^{2-}$ and $\left[\mathrm{Cu}(\mathrm{CN})_{4}\right]^{3-}$. $\mathrm{CuCN}$, a white crystalline poisonous powder, is produced by the reaction of cuprous chloride and sodium cyanide and used mainly in electroplating, due to its ability to form complex cyanides. It contains approx. $71 \%$ of copper and is produced as follows:

a. by the reduction of copper(II) sulfate with sodium bisulphite at $60{ }^{\circ} \mathrm{C}$, followed by the addition of sodium cyanide to precipitate pure LT-CuCN as a pale yellow powder (2 $\left.\mathrm{CuSO}_{4}+\mathrm{NaHSO}_{3}+\mathrm{H}_{2} \mathrm{O}+2 \mathrm{NaCN} \rightarrow 2 \mathrm{CuCN}+3 \mathrm{NaHSO}_{4}\right)$. By the addition of sodium bisulphite the copper sulphate solution becomes green, at that point sodium cyanide should be added.

b. by treating copper(II) sulfate with sodium cynide in a redox reaction, copper(I) cyanide forms together with cyanogen $\left(2 \mathrm{CuSO}_{4}+4 \mathrm{NaCN} \rightarrow 2 \mathrm{CuCN}+(\mathrm{CN})_{2}+2 \mathrm{Na}_{2} \mathrm{SO}_{4}\right)$

It is used as a fumigant in agriculture. The principal use of hydrogen cyanide is in the manufacture process of acrylates, synthetic fibres, plastics and cyanide salts and pesticides. Cyanide salts are utilized in metal cleaning, gardening, invarious organic reactions in manufacture production. It is also used for the production of monomers (e.g. acrylates) as well as an ingredient of fumigants and pesticides. Copper compounds form a protective barrier on the plant surface and thereby prevent fungi from entering the plant host. The copper compounds as non-systemic fungicides operate as Bordeaux mixture, cupric hydroxide, copper arsenate, copper carbonate, cuprous oxide, copper oxychloride etc.

Synonyms of copper cyanide are cianuro de cobre (Spain); Kupfercyanid (Germany); cyanure de cuivre (France).

\subsubsection{Copper naphthenate}

Copper naphthenate is a copper salt of naphthenic acid, which is a complex natural mixture of fatty acids, by-product of petroleum refining and it takes part in variable compositions (contaminants, inert, and by-products). Naphthenates are mainly applied for industrial use, including the oriduction of synthetic detergents, lubricants, corrosion inhibitors, fuel and lubricating oil additives, wood preservations, insecticides, fungicides, acaricides, wetting agents as well as oil drying agents used in painting and wood surface treatment. A typical copper naphthenate product appears as a green liquid with about $19 \%$ copper naphthenate and $81 \%$ unlisted ingredients. The cyclopentylacetic acid, alkyl-substituted cyclopentylacetic acids, fused chains of cyclopentylacetic acids, cyclohexylacetic acids, cyclopentanoic acids, and various low-molecular-weight fatty acids all represent frequent constituents of naphthenic acids. 
Copper naphthenate in terms of new and environmentally-sound timber preservatives presents an alternative to the use of restricted pesticides. It offers positive benefits with regards to safety, performance, application and the environment; furthermore it is not classified as a "Restricted Use Pesticide", nor does it contain dioxins, carcinogens, chrome arsenic, lindane, pentachlorophenol (PCP) or tributyltin oxide (TBTO). Copper naphthenate products are highly effective against wood-destroying fungi and insects; $\mathrm{Cu}$ salt prevents also fungal decay and insect attack, furthermore water resistant features of naphthenate prevent rot and elongate life expectancy of timber.

\subsubsection{Copper soap}

Copper soap known also as copper octanoate or octanoic acid (as active agent in conc. approx. $0.08 \%$ ), copper soap is mostly used to control fungal and bacterial plant diseases (powdery mildew, blackspot, blight, downy mildew, gray mold and many others affecting flowers, fruits and vegetables). Copper soap is produced by combining a soluble $\mathrm{Cu}$ fertilizer with a naturally-occurring fatty acid. Copper and the fatty acid together form copper salt of fatty acids, technically known as soap with a copper concentration lower than $90 \mathrm{ppm}$. The soap has to be applied by spraying all plant surfaces two weeks before infection and occurrence of the disease. In agriculture, it can be mixed with other pesticides as well and applied by ground equipment or aircraft. It should be applied at first signs of disease and repeated every 7-10 days until favourable disease conditions are no longer present.

\section{Copper and human health: Fruit and vegetable}

Copper is an essential element for the normal healthy growth and reproduction of all higher plants and animals, especially in the context of haemoglobin in the blood, formation of collagen and it is protective coverings for nerves. In combination with other metallic elements, along fatty and amino acids as well as vitamins, $\mathrm{Cu}$ is necessary for normal metabolic processes. The human body is unable to produce metals; therefore the human diet must supply regular amounts of bioavailable $\mathrm{Cu}$.

$\mathrm{Cu}$ is present in different species and varieties of plants especially in fruits and vegetables, nuts, seeds, chickpeas, liver, oysters and in some water. Satisfactory amounts of copper that provide up to $50 \%$ of the required whole intake in a balanced diet can be found also in other cereals, meat and fish. Copper deficiency can lead to coronary diseases, higher cholesterol levels, premature births, chronic diarrhoea, stomach diseases, nauseas and other adverse effects, that are observed in most developed countries as well. Copper is incorporated in certain proteins, which are involved in the production of energy required in biochemical reactions, while others take part in the transformation of melanin essential for the pigmentation of the skin. Many of these help maintaining and repairing connective tissues indispensable for the proper functions of heart and arteries. Copper has been used as a medicine for thousands of years including the treatment of chest wounds and treating drinking water. More recently, research has indicated that copper helps prevent inflammation in arthritis and similar diseases.

The quantity of copper at an adult person ranges from 1.4 to $2.1 \mathrm{mg}$ per kilogramme of body weight. The average daily uptake of copper should be from $0.4 \mathrm{mg}$ for children up to $1.2 \mathrm{mg}$ 
for adults. The World Health Organisation (WHO) and the Food and Agricultural Administration (FAA) suggest that the daily mean intake of copper should not exceed 12 mg. These mean values are not to be generalized as in some cases already these intake amounts can cause undesirable effects, in rare cases also diseases like childhood cirrhosis, liver damage and hereditary diseases such as Wilson's Disease. Chronic copper poisoning is very rare, mostly reported at patients with liver disease. The capacity for healthy human livers to excrete copper is considerable and yet no cases of chronic copper poisoning have been reported. The sources of $\mathrm{Cu}$ contents in fruits and vegetables can be described as ecological (parental matter, participation, concentration of $\mathrm{Cu}$ in soil) and growing (spraying, fertilization) conditions and plant physiological and biochemical processes (state of health, phonological stage) (Table 5).

\begin{tabular}{|c|c|}
\hline Fruits & Content mg $100 \mathrm{~g}^{-1}$ \\
\hline Peach (dried) & 0.6 \\
\hline Black Currants (dried) & 0.5 \\
\hline Sultanas (dried) & 0.4 \\
\hline Lemon (slice) & 0.3 \\
\hline Apricot (dried) & 0.3 \\
\hline Grape (fresh) & $0.1\left(1.4^{*}\right)$ \\
\hline \multicolumn{2}{|l|}{ Nuts } \\
\hline Brazil nuts & 1.1 \\
\hline Coconut (desiccated) & 0.6 \\
\hline Walnuts & 0.3 \\
\hline \multicolumn{2}{|l|}{ Vegetable/other } \\
\hline Cabbage, Pumpkin & $0.9-1.4$ \\
\hline Pepper & 1.1 \\
\hline Mushroom & 0.6 \\
\hline Parsley & 0.5 \\
\hline Chickpeas & 0.3 \\
\hline Peas & 0.3 \\
\hline Spinach & 0.3 \\
\hline
\end{tabular}

* Sprayed grape (Provenzano et al., 2010)

Table 5. Fruits and vegetables with highest contents (mg 100g-1) of copper 


\section{Conclusions}

Copper is still an irreplaceable metal regarding disease control in horticulture, especially nowadays with the biological food production gaining in importance. Although we are well aware of the risks of its permanent use, concerning its accumulation and pollution of soils as well as its high residues in fruits and vegetables (fresh consumption), this however does not diminish. On the other hand copper plays an important role as an essential element in many physiological and biochemical processes in higher organisms. Consumers should though avoid excessive daily uptakes. Copper in all its different chemical forms will in near future remain the most important agens in pathogen control in horticulture; therefore its use should be controlled and adapted to environmentally-sound conditions and plant necessities.

\section{References}

Alloway, B.J.; Jewell, A.W. \& Murray, B.G. (1985). Pollen development in copper deficient cereals. University of London, New York.

Brun, L.A.; Maillet, J.; Richarte, J.; Herrmann, P. \& Rémy, J.C. (1998). Relationships between extractable copper, soil properties and copper uptake by wild plants in vineyard soils. Environmental Pollution, Vol.102, No.2, pp. 151-61, ISSN 02697491

Kühn, H. (1997). Verdigris in Copper Resinate, In: Artists' Pigments: A Handbook of Their History and Characteristics Interaction with Art and Antiquities, R. Ashok, (Ed.), 131158, University Press, ISBN 0894682601, Oxford, England

Lepp, N.Y. (1981). Effect of heavy metal pollution on plants. In: Effects of trace metals in plant function, Lepp N.Y., pp. 1-26, Applied Science Publishers, ISBN 0-85334-923-1, London, England

Provenzano, M.R.; El Bilali; H., Simeone; V., Baser, N.; Mondelli, D. \& Cesari, G. (2010). Copper contents in grapes and wines from a Mediterranean organic vineyard. Food Chemistry, Vol.122, No.4, ISNN 0308-8146, 1338-1343

Reed, S.T. \& Martens, D.C. (1996). Copper and zinc, In: Methods of soil analysis, D.L. Sparks et al. (Eds.), 703-722, American Society of Agronomy, ISBN 0-89118-825-8, Madison, Wisconsin, USA

Rusjan, D.; Strlič, M.; Pucko, D. \& Korošec-Koruza, Z. (2007). Copper accumulation regarding the soil characteristics in sub-Mediterranean vineyards in Slovenia. Geoderma, Vol.141, No.1-2, pp. 111-8, ISSN 0016-7061

Ross, S. M. (1994). Toxic Metals in Soil-Plant Systems, John Wiley and Sons, ISBN 0-471-942790 , New York, USA

Sandmann, G. \& Böger, P. (1983). The enzymatological function of heavy metals and their role in electron transfer processes of plants, In: Encyclopedia of Plant Physiology, A. Lauchli \& R.L. Bieleski (Eds.), pp. 563-596, Springer-Verlag, ISBN 3-540-12130-X, Berlin, Germany

Šajn, R.; Bidovec, M.; Gosar, M. \& Pirc, S. (1998). Geochemical soil survey at Jesenice area, Slovenia. Geologija, Vol.41, No.1, pp. 319-338, ISSN 1392-110X 
Woolhouse, H.W. \& Walker, S. (1981). The physiological basis of copper toxicity and tolerance in higher plants, In: Copper in Soils and Plants, J.F. Loneragan, A.D. Robson, R.D. Graham (Eds.), 265-285, Academic Press, ISBN 0-12-455520-9, Sydney, Australia 


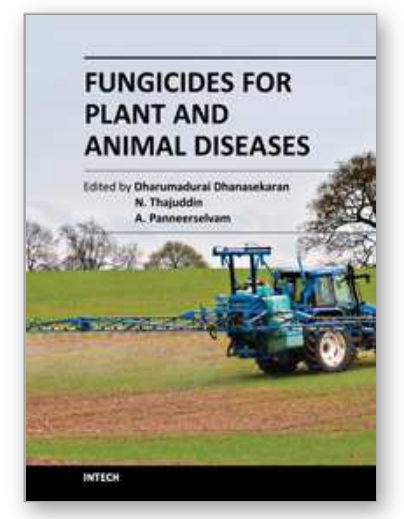

\author{
Fungicides for Plant and Animal Diseases \\ Edited by Dr. Dharumadurai Dhanasekaran
}

ISBN 978-953-307-804-5

Hard cover, 298 pages

Publisher InTech

Published online 13, January, 2012

Published in print edition January, 2012

A fungicide is a chemical pesticide compound that kills or inhibits the growth of fungi. In agriculture, fungicide is used to control fungi that threaten to destroy or compromise crops. Fungicides for Plant and Animal Diseases is a book that has been written to present the most significant advances in disciplines related to fungicides. This book comprises of 14 chapters considering the application of fungicides in the control and management of fungal diseases, which will be very helpful to the undergraduate and postgraduate students, researchers, teachers of microbiology, biotechnology, agriculture and horticulture.

\title{
How to reference
}

In order to correctly reference this scholarly work, feel free to copy and paste the following:

Denis Rusjan (2012). Copper in Horticulture, Fungicides for Plant and Animal Diseases, Dr. Dharumadurai Dhanasekaran (Ed.), ISBN: 978-953-307-804-5, InTech, Available from:

http://www.intechopen.com/books/fungicides-for-plant-and-animal-diseases/copper-in-horticulture

\section{INTECH}

open science | open minds

\section{InTech Europe}

University Campus STeP Ri

Slavka Krautzeka 83/A

51000 Rijeka, Croatia

Phone: +385 (51) 770447

Fax: +385 (51) 686166

www.intechopen.com

\section{InTech China}

Unit 405, Office Block, Hotel Equatorial Shanghai

No.65, Yan An Road (West), Shanghai, 200040, China

中国上海市延安西路65号上海国际贵都大饭店办公楼 405 单元

Phone: +86-21-62489820

Fax: $+86-21-62489821$ 
(C) 2012 The Author(s). Licensee IntechOpen. This is an open access article distributed under the terms of the Creative Commons Attribution 3.0 License, which permits unrestricted use, distribution, and reproduction in any medium, provided the original work is properly cited. 